\title{
The Chemical Compounds Analysis of Bio-oil and Char from Cocoa Pod Husks Waste Pyrolysis by GC- MS/FTIR and its Potential as Biofungicide
}

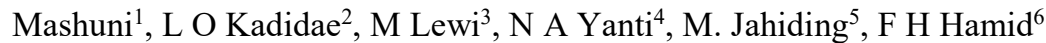 \\ ${ }_{1,2,3,6}$ Department of Chemistry, Faculty of Mathematics and Natural Science, Universitas Halu \\ Oleo, Indonesia. 93132 \\ ${ }^{4}$ Department of Biology, Faculty of Mathematics and Natural Science, Universitas Halu Oleo, \\ Indonesia. 93132 \\ ${ }^{5}$ Department of Physics, Faculty of Mathematics and Natural Science, Universitas Halu Oleo, \\ Indonesia. 93132 \\ \{mashuni2696@gmail.com ${ }^{1}$ \}
}

\begin{abstract}
Cocoa pod husk ( $\mathrm{CPH})$ is a lignocellulosic waste that can be processed for producing chemical compounds. It can be used antifungal active substances which have the potential to become promising biofungicide. The purpose of this study was to obtain active material of bio-oil and char from $\mathrm{CPH}$ pyrolysis as an antifungal. This research include $\mathrm{CPH}$ pyrolysis, compounds analysis of bio-oil and char using Gas Chromatography-Mass Spectrometry/Fourier transform infrared (GC-MS/FTIR) further testing effectiveness as antifungal with the Total Plate Count (TPC) method. The spectrogram of GC-MS shows content of major chemical compounds of bio-oil are 2-methoxy-phenol; 2,3-dimethyl-pyridine; 3methyl-1,2-cyclopentanedione; 2,6-dimethoxy- phenol; 2-butanol; 5-hydroxy-2,7dimethyl-4-octanone; maltol; 3,4-dihydroxyaceto-phenone; 3-methyl-phenol; 2methoxy-5-methylphenol; 2,3-dimethyl-cyclohexanol. The FTIR spectrum of char shows vibration at functional groups $\mathrm{O}-\mathrm{H}, \mathrm{C} \equiv \mathrm{C}, \mathrm{C}=\mathrm{O}$ and $\mathrm{CH} 3$. The concentration of bio-oil $30 \%(\mathrm{v} / \mathrm{v})$ and char effectively inhibit 100\% fungus like control + (synthetic fungicide). Therefore, it is very promising to be applied as biofungicide.
\end{abstract}

Keywords: Antifungal, Bio-Oil, Char, Cocoa pod husk, Pyrolysis.

\section{Introduction}

Cocoa pod husk $(\mathrm{CPH})$ are lignocellulosic waste and it is the main byproduct of the chocolate industry [1]. Lignocellulose materials are naturally designed composites that play crucial roles in the survival of plants [2]. Lignocellulosic materials are mainly composed of cellulose (35-50 $\%)$, hemicellulose $(15-35 \%)$, and lignin (10-35\%). The concentration of the mentioned components varies with plant types [3]. Cellulose is the main structural constituent in plant cell walls and is found in an organized fibrous structure. The long-chain cellulose polymers are linked together by hydrogen and Van Der Waals bonds, which cause the cellulose to be packed 
into microfibrils. Hemicelluloses and lignin cover the microfibrils. Cellulose in biomass is present in both crystalline and amorphous forms [4]. The main feature that differentiates hemicellulose from cellulose is that hemicellulose has branches with short lateral chains consisting of different sugars [5]. Lignin is a complex, large molecular structure containing cross-linked polymers of phenolic monomers. It is present in the primary cell wall, imparting structural support, impermeability, and resistance against microbial attack. Three phenyl propionic alcohols exist as monomers of lignin: coniferyl alcohol (guaiacyl propanol), coumaryl alcohol ( $p$-hydroxyphenyl propanol), and sinapyl alcohol (syringyl alcohol) [6]. The CPH biomass consists primarily of fibrous materials including $19.7-26.1 \%$ cellulose, $8.7-12.8 \%$ hemicellulose, $14-28 \%$ lignin and $6.0-12.6 \%$ pectin so that it can be used as raw materials for the production of bio-oil and char by the pyrolysis method $[7,8]$.

The pyrolysis is a technology for thermal treatment of biomass to recover a new material and energy [9-11]. The pyrolysis process consists of two main sections, the furnace/reactor, which converts biomass to products volatile vapour bio-oil, non-condensable gas and char [1217]), and a condensing system, which recovers the condensable gases as a liquid product. Biooil is a complex mixture of chemicals including acids, ketones, furans, phenols, hydro sugars and other oxygenates $[18,19]$.

The $\mathrm{CPH}$ could be made into a value-added material because they are rich in phenolics and are therefore a promising source of these compounds [20]. The $\mathrm{CPH}$ is a good source of phenolic compounds that can function as antioxidants and could be used as ingredients in functional food. Epidemiological studies indicate that phenolic compounds have the potential effect to prevent chronic diseases and also have anticarcinogenic, antiinflammatory, antimicrobial, antifungal and biofungicide [21-23]. Some researchers have tested the effectiveness of bio-oil from organic waste as a natural pesticide [24, 25]. The bio-oil and char from $\mathrm{CPH}$ pyrolysis can be used as biofungicides because they contain active compounds which are effective as inhibitors of fungal and bacterial growth.

The first step in cocoa cultivation in supporting the development of cocoa plants is by providing seeds that are suitable to be planted in the field so as to produce cocoa plants that are able to produce optimally [26]. Cocoa seed have properties that are not resistant to moisture, temperature and humidity. This causes the cocoa seed to be easily contaminated with fungi during the storage process [27]. Efforts to maintain seed quality can be done using seed storage media [28]. Storage media that can be used include using char which is able to maintain the ideal moisture content of the seed during storage. The use of char storage media acts as a buffer of moisture during storage, which is to provide water if the cocoa seed is lacking in water and otherwise absorbs water if the cocoa seed is excessive, so char can play a role in improving the quality of cocoa seed during the storage period.

\section{Material and Methods}

\subsection{Materials}

The cacao pod husks $(\mathrm{CPH})$ were obtained from a cacao plantation in Lambandia, East Kolaka, Southeast Sulawesi Province, located in Eastern Indonesia. The CPH is dried under the sun for 6-7 days then cut them into pieces up to $2-3 \mathrm{~cm}$ in size.

\subsection{Pyrolysis Method}

Dried CPH samples (1000 g) was put into a pyrolysis reactor which was equipped with a series of condensers and thermocouples. Pyrolysis was carried out at $500{ }^{\circ} \mathrm{C}$ for $\pm 2-3$ hours [9] 
with a heating flow rate of $6{ }^{\circ} \mathrm{C} /$ minute. Pyrolysis was stopped after no more bio-oil dripped into the reservoir. The results of pyrolysis were bio-oil, tar and char. Bio-oil from pyrolysis was filtered using whatman filter paper coated with gauze and activated carbon to obtain clear biooil. Other pyrolysis product, namely char, was mashed up to 80 mesh in size for cocoa seed storage media.

\subsection{The Chemical Compound Analysis of Bio-oil and Char by GC-MS/FTIR}

The chemical compound analysis of bio-oil content was carried out using GC-MS instrument. Each of bio-oil sample, as much as $1 \mu \mathrm{L}$ was injected into Thermo Scientific GCMS Trace $1300 \mathrm{GC} / \mathrm{ISQ}$ with ionizing type EI (Electron Impact) $70 \mathrm{ev}$, injector temperature and detector $290^{\circ} \mathrm{C}$, column temperature $70^{\circ} \mathrm{C}$ to $280^{\circ} \mathrm{C}, 30 \mathrm{~m}$ column length, $25 \mathrm{~mm}$ diameter in column, $5^{\circ} \mathrm{C}$ temperature rise per minute, $100 \mathrm{kPa}$ helium carrier gas, flow rate of $60 \mathrm{ml} / \mathrm{min}$. Compounds were identified by comparing retention times to well-characterised materials. The analysis of char using FTIR Thermo Scientific Nicolet iS 10 with beam splitter $\mathrm{KBr} / \mathrm{Ge}$ midinfrared and detector type Deuterated Tri-Glycine Sulfate (DTGS) to determine the functional group contained. The scanning range of the FTIR was set to $4000-650 \mathrm{~cm}^{-1}$ at $8 \mathrm{~cm}^{-1}$ resolution with OMNIC FTIR software.

\subsection{The Effectiveness Test of Bio-oil and Char as Biopesticides}

The supply of cocoa seed was prepared by removing the cocoa pod to take the middle part of the fruit. The cocoa beans were collected and cleaned up from the pulp using sawdust, then the skin of the beans were removed. Cocoa beans are washed thoroughly with water then immersed into bio-oil, synthetic fungicide (control+) and water (control-) for 10-15 minutes. Soaked cocoa beans are dried in an open room without sunlight then some are covered with char. Futhermore, they were stored for 12 days [29]. Observation of the antifungal effectiveness of bio-oil and char used the TPC method.

\section{Results and Discussion}

The CPH pyrolysis produces bio-oil, tar and char. It also obtained the gases which can not be condensed by cooling, so it could not be accommodated in the liquid reservoir. Most of these gases are trapped in the container while others apart from the reservoir through the conduit of smoke and escape into the atmosphere [10]. The rendemen of $\mathrm{CPH}$ pyrolysis was $35 \pm 5 \%$ for bio-oil, $5 \pm 1 \%$ for tar and $30 \pm 2 \%$ for char. The CPH bio-oil has a density of $1.085 \pm 0.003 \mathrm{~g}$ $\mathrm{ml}^{-1}$. The volume of bio-oil produced is influenced by decomposition and depolymerization of cellulose during pyrolysis [30].

\subsection{The Chemical Compound Content of Bio-oil and Char from CPH Pyrolysis}

Figure 1 shows the analysis from GC/MS of CPH bio-oil, and the corresponding identified compounds are listed in Table 1. The compounds' content was determined by using standard NIST MS software. The percentage peak areas correspond to the relative yields of the products among all of the identified components. 


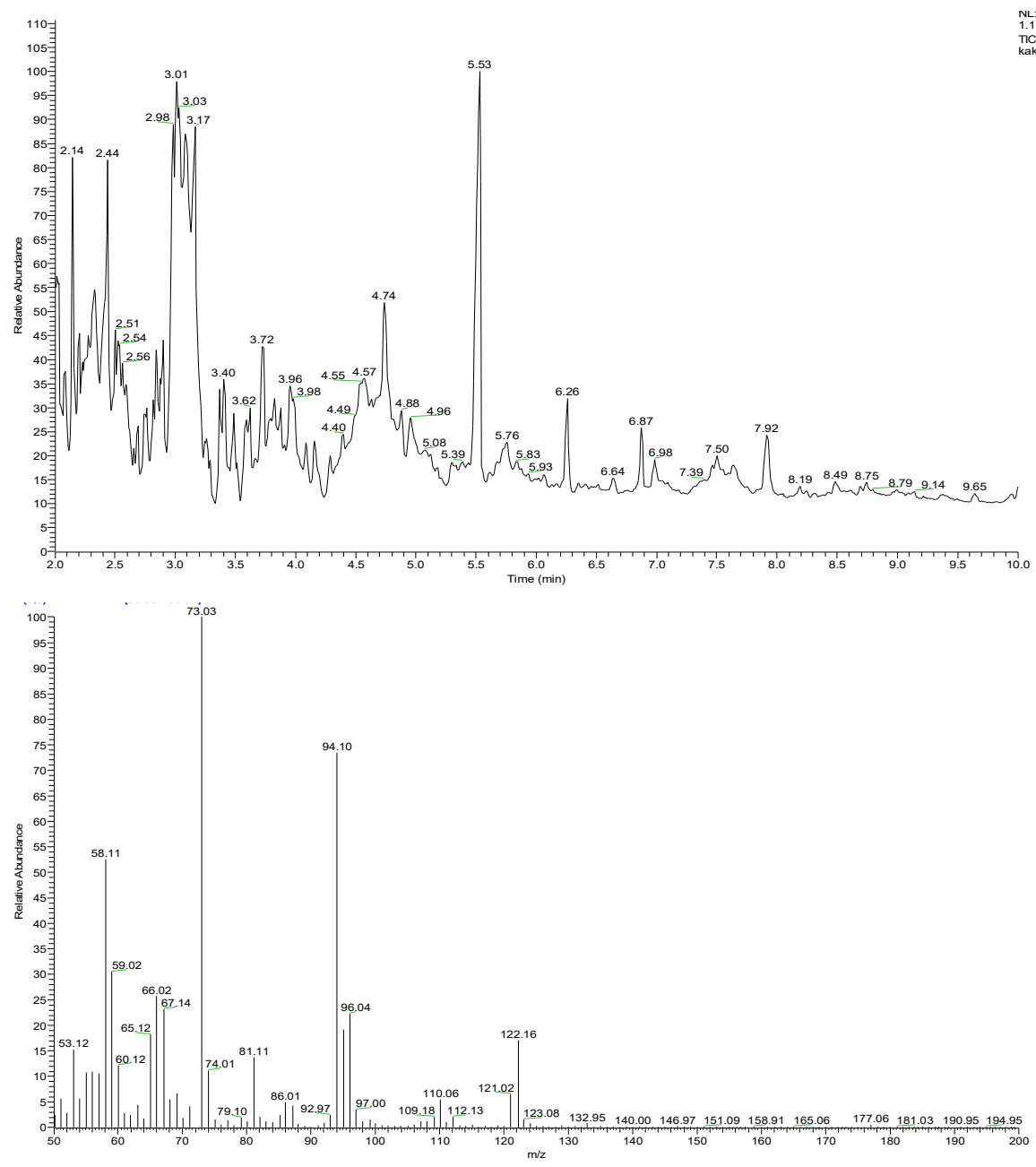

Fig. 1. GC-MS spechtrogram of CPH bio-oil

Table 1 . The chemical compound of CPH bio-oil

\begin{tabular}{clccc}
\hline $\begin{array}{c}\text { Retention } \\
\text { time } \\
\text { (minute) }\end{array}$ & \multicolumn{1}{c}{ Compound Name } & $\begin{array}{c}\text { Chemical } \\
\text { formula }\end{array}$ & Area (\%) & $\begin{array}{c}\text { Molecular } \\
\text { Weight }\end{array}$ \\
\hline 2.14 & 3-methyl-pyridine & $\mathrm{C}_{6} \mathrm{H}_{7} \mathrm{~N}$ & 2.08 & 93 \\
2.33 & 2-Butanol & $\mathrm{C}_{4} \mathrm{H}_{10} \mathrm{O}$ & 6.88 & 74 \\
2.44 & 2,3-dimethyl-pyridine & $\mathrm{C}_{7} \mathrm{H}_{9} \mathrm{~N}$ & 9.29 & 107 \\
3.01 & 2-methoxy-phenol & $\mathrm{C}_{7} \mathrm{H}_{8} \mathrm{O}_{2}$ & 24.19 & 124 \\
3.17 & 3-methyl-1,2-cyclopentanedione & $\mathrm{C}_{6} \mathrm{H}_{8} \mathrm{O}_{2}$ & 8.04 & 112 \\
3.40 & 3-methyl-phenol & $\mathrm{C}_{7} \mathrm{H}_{8} \mathrm{O}$ & 3.86 & 108 \\
3.62 & 1,2,3-trimethyldiaziridine & $\mathrm{C}_{4} \mathrm{H}_{10} \mathrm{~N}_{2}$ & 1.85 & 86 \\
3.72 & Maltol & $\mathrm{C}_{6} \mathrm{H}_{6} \mathrm{O}_{3}$ & 6.15 & 126 \\
3.96 & 2-methoxy-5-methylphenol & $\mathrm{C}_{8} \mathrm{H}_{10} \mathrm{O}_{2}$ & 3.20 & 138 \\
& & & &
\end{tabular}




\begin{tabular}{lllll}
4.74 & 3,4-dihydroxyacetophenone & $\mathrm{C}_{8} \mathrm{H}_{8} \mathrm{O}_{3}$ & 5.21 & 152 \\
5.53 & 2,6-dimethoxy- phenol & $\mathrm{C}_{8} \mathrm{H}_{10} \mathrm{O}_{3}$ & 7.18 & 154 \\
5.76 & 2,3-dimethyl- cyclohexanol & $\mathrm{C}_{8} \mathrm{H}_{16} \mathrm{O}$ & 2.63 & 128 \\
6.26 & Dehydroacetic Acid & $\mathrm{C}_{8} \mathrm{H}_{8} \mathrm{O}_{4}$ & 1.08 & 168 \\
7.92 & 4-(ethoxymethyl)-2-methoxy-phenol & $\mathrm{C}_{10} \mathrm{H}_{14} \mathrm{O}_{3}$ & 1.20 & 182 \\
\hline
\end{tabular}

Figure 1 and Table 1 show that CPH bio-oil predominantly contains phenolic compounds such as 2-methoxy-phenol (24.19\%); 2,6-dimethoxy- phenol (7.18\%); 3-methyl-phenol (3.86\%); 2-methoxy-5-methylphenol (3.20\%); 4-(ethoxymethyl)-2-methoxy-phenol (1.20\%) and ketone i.e. 3,4-dihydroxyacetophenone (5.21\%). Phenolic and ketone compounds have antifungal and antimicrobial effectiveness [24]. In addition, $\mathrm{CPH}$ bio-oil contains pyridine compounds, i.e. 2,5-dimethyl-pyridine $(9.29 \%)$ and 3-methyl-pyridine $(2.08 \%)$. Pyridine compound is an integral part of DNA and RNA that has pharmacological properties and effective as bactericide and fungicide [31].

In this study FTIR was used for the analysis of char from the result of CPH pyrolysis. This was intended to determine the functional group contained in char, which was used as a protective media for seed from fungal attack. The FTIR spectrum of CPH char was presented in Figure 2.

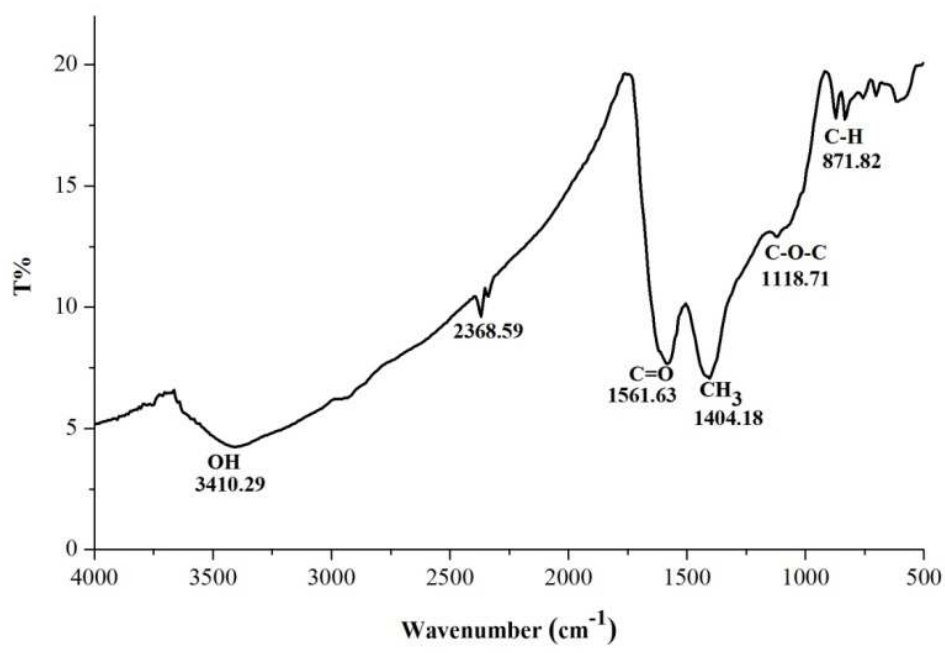

Fig. 2. The FTIR spectrum of CPH char

Tabel 2. The spectrum region of $\mathrm{CPH}$ char

\begin{tabular}{ccc}
\hline No & Wavenumber $\left(\mathrm{cm}^{-1}\right)$ & Functional group \\
\hline 1 & 3410.29 & $\mathrm{O}-\mathrm{H}$ \\
2 & 2368.59 & $\mathrm{C} \equiv \mathrm{C}$ \\
3 & 1561.63 & $\mathrm{C}=\mathrm{C}$ \\
4 & 1404.18 & $\mathrm{CH} 3$ \\
5 & 1118.72 & $\mathrm{C}-\mathrm{O}-\mathrm{C}$ \\
6 & 871.81 & $\mathrm{C}-\mathrm{H}$ \\
\hline
\end{tabular}

Adsorption in the infrared (IR) region takes place $\left(4000-400 \mathrm{~cm}^{-1}\right)$ due to the rotational and vibrational movement of the molecular groups and chemical bond of a molecule [32]. The FTIR spectrum was obtained to evaluate qualitatively the chemical structures of CPH char. The FTIR 
analysis of $\mathrm{CPH}$ char (Figure 2) shows the absorption of wavenumbers $3410.29 \mathrm{~cm}^{-1}$, this indicates the presence of a hydroxyl functional group $(\mathrm{O}-\mathrm{H})$. The spectrum at wavenumber 2368.59 is identified as a functional group of $\mathrm{C} \equiv \mathrm{C}$. The region of the spectrum of $1561.63 \mathrm{~cm}^{-1}$ is attributed to deformation of aromatics groups $\mathrm{C}=\mathrm{C}$ stretching, whereas the peak around $1404.18 \mathrm{~cm}^{-1}$ could correspond to the $\mathrm{CH}_{3}$ deformation of the $\mathrm{CPH}$ char. The $\mathrm{C}-\mathrm{O}-\mathrm{C}$ stretching band is typical of the peak observed at $1118.72 \mathrm{~cm}^{-1}$ and the peak at $871.81 \mathrm{~cm}^{-1}$ could also be attributed to the C-H out-of-plane bending. The results of FTIR analysis reported by previous researchers showing functional groups contained in $\mathrm{CPH}$ char are hydroxyl $\mathrm{O}-\mathrm{H}$ groups (phenol and alcohol), $\mathrm{C}=\mathrm{CH}$ aromatic, $\mathrm{CH}$ and $\mathrm{CH}_{2}$ aliphatic and other carbon atom compounds [33-35] which have potential as biofungicides and moisture buffer.

\subsection{The Analysis of Characteristics and Effectiveness of Antifungals on Cocoa Seeds}

Improving of the quality of cocoa seeds is influenced by several factors that can cause overall changes in seeds including physically, physiologically and chemically. Changes in seed quality can occur during storage periods and it is usually caused by fungal attacks, high water content and changes in $\mathrm{pH}[36]$.

\subsubsection{The pH and Water Content Analysis of Cocoa Seeds}

Efforts to improve the quality of cocoa seeds have several inhibiting factors, one of which is the acidity of the seed. If the $\mathrm{pH}$ of cocoa seeds is $\leq 5$ or $\geq 6$, the quality of seed sprouts will decrease. The results of the measurement of $\mathrm{pH}$ on cocoa seeds from each treatment during a storage period of 12 days with a measurement interval of 3 days ranged from 5-6. This result is in accordance with SNI 01-2323-2000 standards regarding cocoa seeds. The $\mathrm{pH}$ of the seed approaching the base is likely to result in absorption of nutrients and the activity of microorganisms running fast. While the low $\mathrm{pH}$ can affect microbial activity so that the mechanism of providing nutrients through the process of decomposition of organic matter on the soil will be difficult [37].

The quality of cocoa seeds is strongly influenced by the water content in the seeds, because the high and low water content of the seeds can cause damage or even death of cacao seeds [38]. Based on the results of the research on the water content of cocoa seeds in each treatment for 12 days the storage period, with an interval of 3 days the test time decreased i.e. on the early day the water content of $75 \%$ decreased to $27 \%$ on the 12 th day. Based on the results of the study of water content until the 6th day in all treatments, it still met the quality standards of cocoa seeds while those on day 9 to day 12 were below the minimum threshold of seed provisions, namely 30-40\% [39] (Figure 3). 


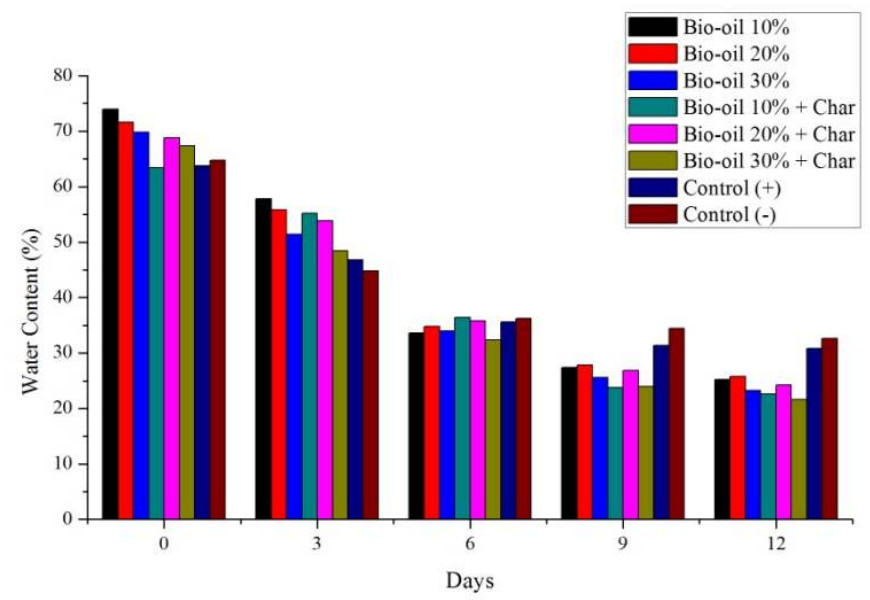

Fig. 3. The water content of cocoa seeds

\subsubsection{The Antifungal Effectiveness of Bio-oil and Char on Cocoa Seeds}

Bio-oil and char are media that are used as active ingredients to inhibit the growth of fungi and other microbes in seeds during the storage period [40]. The ability of bio-oil and char to inhibit the growth of mold on seeds during the storage period can be seen the TPC in Table 3 .

Tabel 3. The TPC (CFU/g) on cocoa seeds after 2 days of incubation and 10 days of storage

\begin{tabular}{cc}
\hline Treatment & TPC $(\mathrm{CFU} / \mathrm{g})$ \\
\hline Bio-oil 10\% & $37 \times 10^{2}$ \\
Bio-oil 20\% & $7.5 \times 10^{2}$ \\
Bio-oil 30\% & - \\
Bio-oil 10\% + char & $18.5 \times 10^{2}$ \\
Bio-oil 20\% + char & $1 \times 10^{2}$ \\
Bio-oil 30\% + char & - \\
Control (+) & - \\
Control (-) & $72.5 \times 10^{2}$ \\
\hline
\end{tabular}

Table 3 shows that cacao seeds treated with a bio-oil $10 \%$ concentration have a low power to inhibit fungal growth with TPC is $37 \times 10^{2} \mathrm{CFU} / \mathrm{g}$ and the addition of char covering, it can reduce fungal growth characterized by TPC $18.5 \times 10^{2} \mathrm{CFU} / \mathrm{g}$. At bio-oil concentration $20 \%$ gives a greater inhibition of fungal growth compared to the $10 \%$ bio-oil with TPC $7.5 \times 10^{2}$ $\mathrm{CFU} / \mathrm{g}$ and the addition of char covering causes a further increase of inhibitory ability characterized by the TPC $1 \times 10^{2} \mathrm{CFU} / \mathrm{g}$. The $30 \%$ bio-oil concentration showed the greatest antimicrobial activity compared to other concentrations because it was able to kill fungi characterized by the absence of fungi growing on the media, the same effect that was shown by synthetic fungicides. The results of this study are in accordance with SNI 7388: 2009 stating that the cacao seeds given bio-oil and carbon-covered did not exceed the maximum limit of the number of fungal colonies on cacao seeds, which was equal to $1 \times 10^{4} \mathrm{CFU} / \mathrm{g}$ [41]. 


\section{Conclusion}

The GC-MS spectrogram of bio-oil from CPH pyrolysis shows the presence of chemical compounds: 2-methoxy-phenol; 2-methoxy-phenol; 2,6-dimethoxy- phenol; 3-methyl-phenol; 2-methoxy-5-methylphenol; 4-(ethoxymethyl)-2-methoxy-phenol; 3,4-dihydroxyacetophenone; 2,5-dimethyl-pyridine and 3-methyl-pyridine. Furthermore, the FTIR spectrum of char from $\mathrm{CPH}$ pyrolysis shows functional groups of the substances are O-H hydroxyl (phenol and alcohol), $\mathrm{C}=\mathrm{CH}$ aromatic, $\mathrm{CH}$ and $\mathrm{CH}_{2}$ aliphatic. The presence of phenolic, ketone, alcohol and pyridine compounds make bio-oil and char can be used as antifungals during preparation of cocoa seeds. Characteristics of cacao seeds during the storage period were: $\mathrm{pH}$ ranged from 5 to 6 for 12 days of storage period and water content of $30 \%-40 \%$ for 6 days of storage period. The ability of bio oil and char from $\mathrm{CPH}$ pyrolysis in inhibiting fungal growth in the preparation of cocoa seeds is comparable to the synthetic fungicides so that they can be applied as biofungicides.

\section{Acknowledgements}

This research was supported by Kemenristekdikti through the PSN-Institution and Applied research program for the 2018-2019 budget year and We thank our to Halu Oleo University who provided insight and expertise that greatly assisted research.

\section{References}

[1] L. Valadez-Carmona, A. Ortiz-Moreno, G. Ceballos-Reyes, J. A. Mendiola, and E. Ibáñez, Valorization of cacao pod husk through supercritical fluid extraction of phenolic compounds, J. Supercrit. Fluids, vol. 131, pp. 99-105. doi: 10.1016/j.supflu.2017.09.011 (2018)

[2] A. Zamani, Introduction to Lignocellulose-based Products: Lignocellulose-Based Bioproducts, vol. 1, pp. 1-36, Ed. K. Karimi, London: Springer International Publishing Switzerland (2015)

[3] P. Azadi, O. R. Inderwildi, R. Farnood, and D. A. King, Liquid fuels, hydrogen and chemicals from lignin: A critical review, Renew. Sustain. Energy Rev., vol. 21, pp. 506523 doi: 10.1016/j.rser.2012.12.022 (2013)

[4] P. Béguin and J. P. Aubert, The biological degradation of cellulose, FEMS Microbiol. Rev., vol. 13, pp. 25-58, doi: 10.1016/0168-6445(94)90099-X (1994)

[5] R. C. Kuhad, A. Singh, and K.-E. L. Eriksson, Microorganisms and enzymes involved in the degradation of plant fiber cell walls, vol. 57. Berlin: Springer-Verlag Berlin Heidelberg (1997)

[6] C.L. Hii, C.L. Law, S.Suzannah, Misnawi and M. Cloke, Polyphenols in cacao (Theobroma cacao L.), Asian J. Food Agro-Industry, vol. 2, pp. $702-722$ (2009)

[7] O. Sobamiwa and O. G. Longe, Utilization of cocoa-pod pericarp fractions in broiler chick diets, Anim. Feed Sci. Technol., vol. 47, pp. 237-244. doi: 10.1016/0377-8401(94)901279 (1994)

[8] O. Adeyi, Proximate composition of some agricultural wastes in Nigeria and their potential use in activated carbon production, J. Appl. Sci. Environ. Manag., vol. 14, pp. 55-58. doi: 10.4314/jasem.v14i1.56490 (2010) 
[9] Mashuni, N. A. Yanti, M. Jahiding, and M. Edihar, Validation of UV-Vis Spectrophotometric Method for Determination of Bio oil Total Phenolic Content from Pyrolisis of Cashew Nut Shell, Res. J. Pharm. , Biol. Chem. Sci., vol. 8, pp. 1745-1752 (2017)

[10] Mashuni M. Jahiding, W.O.S. Ilmawati, I. Kurniasih, W. Wati, Muzirah and M. Burhan, Characterization of Liquid Volatile Matter (LVM) of Cashew Nut Shell using Pyrolysis and Gas Chomatroghaphy, J. Phys. Conf. Ser., vol. 846, pp. 1-6. doi: 10.1088/17426596/846/1/012026 (2017)

[11] J. P. Girard, Smooking in Technology of Meat and Meat Products. New York: Ellis Horwood (1992)

[12] A. E. Pütün, N. Özbay, E. P. Önal, and E. Pütün, "Fixed-bed pyrolysis of cotton stalk for liquid and solid products," Fuel Process. Technol., vol. 86, pp. 1207-1219. doi: 10.1016/j.fuproc.2004.12.006 (2005)

[13] A. Demirbas, The Influence of Temperature on the Yields of Compounds Existing in Biooils Obtained from Biomass Samples Via Pyrolysis, Feul Processing Technology, vol. 88, pp. 591-597. doi: 10.1016/j.fuproc.2007.01.010 (2007)

[14] S. Papari and K. Hawboldt, Development and Validation of a Process Model to Describe Pyrolysis of Forestry Residues in an Auger Reactor, Energy and Fuels, vol. 31, pp. 1083310841. doi: 10.1021/acs.energyfuels.7b01263 (2017)

[15] S. Papari and K. Hawboldt, A Review on the Pyrolysis of Woody Biomass to Bio-oil: Focus on Kinetic Models, Renew. Sustain. Energy Rev., vol. 52, pp. 1580-1595. doi: 10.1016/j.rser.2015.07.191 (2015)

[16] H. Bamdad, K. Hawboldt, and S. MacQuarrie, A Review on Common Adsorbents for Acid Gases Removal: Focus on Biochar, Renew. Sustain. Energy Rev., vol. 81, pp. 1705-1720. doi: 10.1016/j.rser.2017.05.261 (2018)

[17] H. Bamdad and K. Hawboldt, Comparative study between physicochemical characterization of biochar and metal organic frameworks (MOFs) as gas adsorbents, Can. J. Chem. Eng., vol. 94, pp. 2114-2120. doi: 10.1002/cjce.22595 (2016)

[18] A. C. Johansson, H. Wiinikka, L. Sandström, M. Marklund, O. G. W. Öhrman, and J. Narvesjö, Characterization of Pyrolysis Products Produced from Different Nordic Biomass Types in a Cyclone Pilot Plant, Fuel Process. Technol., vol. 146, pp. 9-19. doi: 10.1016/j.fuproc.2016.02.006 (2016)

[19] L. Sandström, A. C. Johansson, H. Wiinikka, O. G. W. Öhrman, and M. Marklund, Pyrolysis of Nordic biomass types in a cyclone pilot plant-Mass balances and yields, Fuel Process. Technol., vol. 152, pp. 274-284. doi: 10.1016/j.fuproc.2016.06.015 (2016)

[20] M. Pallawagau, N. A. Yanti, M. Jahiding, L. O. Kadidae, W. A. Asis, and F. H. Hamid, Penentuan Kandungan Fenolik Total Liquid Volatile Matter dari Pirolisis Kulit Buah Kakao dan Uji Aktivitas Antifungi terhadap Fusarium oxysporum, ALCHEMY Jurnal Penelitian Kimia, vol. 15, pp. 165-176. doi: 10.20961/alchemy.15.1.24678.165-176 (2019)

[21] Mashuni, N. A. Yanti, M. Jahiding, Kartina, and F. H. Hamid, Pemanfaatan Asap Cair Dari Limbah Kulit Kakao Sebagai Antijamur Pada Benih Tanaman Kakao (Theobroma Cacao L.), in Prossiding Seminar Nasional Teknik Kimia Eco-Smart UNS, vol. 15, pp. 8997 (2018)

[22] R. Martínez, P. Torres, M. A. Meneses, J. G. Figueroa, J. A. Pérez-Álvarez, and M. ViudaMartos, Chemical, Technological and in VitroAntioxidant Properties of Cocoa (Theobroma cacao L.) co-products, Food Res. Int., vol. 49, pp. 39-45. doi: 10.1016/j.foodres.2012.08.005 (2012) 
[23] A. M. Farías-Campomanes, M. A. Rostagno, and M. A. A. Meireles, Production of polyphenol extracts from grape bagasse using supercritical fluids: Yield, extract composition and economic evaluation, J. Supercrit. Fluids, vol. 77, pp. 70-78. doi: 10.1016/j.supflu.2013.02.006 (2013)

[24] D. Mourant, B. Riedl, D. Rodrigue, D. Q. Yang, and C. Roy, Phenol-FormaldehydePyrolytic Oil Resins for Wood Preservation: A Rheological Study, J. Appl. Polym. Sci., vol. 106, pp. 1087-1094. doi: 10.1002/app.26817 (2007)

[25] D. Mourant, D. Q. Yang, X. Lu, and C. Roy, Anti-fungal Properties of the Pyroligneous Liquors from the Pyrolysis of Softwood Bark, Wood and Fiber Sci., vol. 37, pp. 542-548 (2007)

[26] Baharudin, I. Satriyas, M. R. Suhartanto, and A. Purwantara, Pengaruh Lama Penyimpanan Dan Perlakuan Benih Terhadap Peningkatan Mutu Benih Kakao Hibrida, J. Pengkaj. Dan Pengemb. Teknol. Pertan., vol. 13, pp. 73-84 (2010)

[27] Aventi, Penelitian Pengukuran Kadar Air Buah, in Seminar Nasional Cendekiawan, vol. 1, pp. 12-27 (2015)

[28] A. Apriyantono, D. Fardiaz, N. L. Puspitasari, S. B. Sedarnawati, and S. Budianto, Petunjuk Laboratorium Analisis Pangan. Bogor: Pusat Antar Universitas Pangan dan Gizi IPB (1989)

[29] PT. Hasfarm Niaga Nusantara, Kebun Benih Kakao F1. Lambandia Sulawesi Tenggara: PT. Hasfarm Niaga Nusantara (2016)

[30] M. Adjin-Tetteh, N. Asiedu, D. Dodoo-Arhin, A. Karam, and P. N. Amaniampong, Thermochemical conversion and characterization of cocoa pod husks a potential agricultural waste from Ghana, Ind. Crops Prod., vol. 119, pp. 304-312. doi: 10.1016/j.indcrop.2018.02.060 (2018)

[31] B. Singh, A. Maheshwari, G. Dak, K. Sharma, and G. Talesara, Studies of Antimicrobial Activities of some 4-thiazolidinone Fused Pyrimidines, [1,5]-benzodiazepines and Their Oxygen Substituted Hydroxylamine Derivatives, Indian J. Pharm. Sci., vol. 72, pp. $607-$ 612. doi: 10.4103/0250-474x.78529 (2011)

[32] A. M. Aljeboree, A. N. Alshirifi, and A. F. Alkaim, Kinetics and equilibrium study for the adsorption of textile dyes on coconut shell activated carbon, Arab. J. Chem., vol. 10, pp. 1-13. doi: 10.1016/j.arabjc.2014.01.020 (2017)

[33] Maemunah and E. Adelina, Lama Penyimpanan dan Invigorasi Terhadap Vigor Bibit Kakao ( Theobroma cacao L .), Media Litbang Sulteng, vol. 2, pp. 56-61 (2009)

[34] R. Sánchez Orozco et al., Characterization of Lignocellulosic Fruit Waste as an Alternative Feedstock for Bioethanol Production, BioResources, vol. 9, pp. 1873-1885. doi: 10.15376/biores.9.2.1873-1885 (2014)

[35] A. R. Coscione, C. A. Abreu, and A. P. Puga, Influence of Pyrolysis Temperature on Cadmium and Zinc Sorption Capacity of Sugar Cane Straw-Derived Biochar, BioResources, vol. 8, pp. 4992-5004. doi: 10.15376/biores.8.4.4992-5004 (2013)

[36] S. Dahlia, Peranan Trichoderma, Mikoriza dan Fospat Terhadap Tanaman Kedelai Pada Tanah Sangat Masam, J. Penelit. Bid. Ilmu Pertan., vol. 3 (2005)

[37] D. W. Tambunsaribu, S. Anwar, and D. R. Lukiwati, Viabilitas benih dan pertumbuhan bibit kakao (Theobroma cacao L) pada beberapa jenis media simpan dan tingkat kelembaban, J. Agro Complex, vol. 1, pp. 135-142 (2017)

[38] Peraturan Menteri Pertanian, Standar Operasional Prosedur Penetapan Kebun Sumber Benih, Sertifikasi Benih, dan Evaluasi Kebun Sumber Benih Tanaman Kakao (Theobroma cacao L.) (2013)

[39] R. D. Pratiwi, R. Rabaniyah, and A. Purwantoro, Pengaruh Jenis dan Kadar Air Media 
Simpan terhadap Viabilitas Benih Lengkeng (Dimocarpus longan Lour.), Vegetalika, vol. 1 doi: $0.22146 /$ veg. 1522 (2012)

[40] A. S. Muliyatni, A. Budiani, and D. Taniwiryono, Aktivitas antibakteri ekstrak kulit buah kakao (Theobroma cacao L.) terhadap Escherichia coli, Bacillus subtilis, dan Staphylococcus aureus, E-Journal Menara Perkeb., vol. 80, pp. 77-84 (2017)

[41] Badan Standar Nasional, Batas Maksimum Cemaran Mikroba dalam Pangan, in SNI 7388:2009, Jakarta: Badan Standarisasi Nasional (2009) 